\title{
Zinc Sulfate As a Growth Disruptor for Spodoptera littoralis With Reference to Histological Changes in Larval Endocrine Glands
}

\author{
Aziza. M.Sharaby ${ }^{*}$; Fatma.M. EL-Hawary and Sawsan.Moawad \\ Pests and Plant Protection Department, National Research Center, Cairo ,Egypt
}

\begin{abstract}
Zinc sulfate $\left(\mathrm{ZnSO}_{4} 7 \mathrm{H}_{2} \mathrm{O}\right)$ was toxicologically, biologically, and physiologically evaluated as insect development inhibitor and endocrine disruptors against the fourth instar larvae of the cotton leaf worm, $S$ .littoralis. Zinc sulfate significantly increased both larval and pupal duration and decreased pupal weight and pupation percentages if compared with control. The fecundity and fertility of females resulted from fed larvae in all mating combinations were remarkably decreased, compared with control. Results showed that females were more sensitive to Znic sulfate than males. Ultrastructure changes of the endocrine glands of larvae as detected by (TEM) were discussed. Zinc sulfate may be used as growth disruptor for $S$. littoralis among other control methods for S.littoralis management.
\end{abstract}

Key words: $S$.littoralis larvae, zinc sulfate, growth disruption, endocrine glands, ultrastructure, histological changes, Electron microscope.

\section{Introduction}

Zinc sulfate $\left(\mathrm{ZnSO}_{4} 7 \mathrm{H}_{2} \mathrm{O}\right)$ is crystal transparent odorless material, water soluble, stable at normal temperature and pressure. It is ideally suitable for providing the nutritional source of Zinc requirements in animal feeds. In agriculture zinc serves as a growth hormone and influence protein synthesis . Zinc deficiency often causes stunting of the plant, yellowing of the leaves, and decreased yield of seed, grains, vegetables or fruits. Zinc sulfate is often used on crops such as pecan, deciduas fruits, peanuts, cotton, corn, vegetables and especially citrus. A solution of zinc sulfate sprayed on soil can increase crop yield. It is also used in animal feed to increase appetite, control blood disorders and bone disease and prevent premature death. In general Zinc sulfate is considered to be of low toxicity. Industrial experiences has not identified any significant chronic effects from it to date. It is not listed as a carcinogenic by the Occupation Safety and Health Administration (OSHA), the National Toxicology Program (NTP), the International Agency for Research on Cancer (ARC), the American Conference of Governmental Industrial Hygienists (ACGH) or European Union (EU)(2) ${ }^{*}$. Zinc sulfate under the right circumstances and handling can be an extremely useful .

Endocrine disrupting compounds (EDC) are known as third generation insecticides. They act as insect growth regulators (IGR) and are considered as potential endocrine disruptors. They interfere with the hormonal system of insects causing adverse effects on the physiological function of the insect or on their progeny. Insects endocrinology is currently an active area of research because it offers the potential for disrupting the life cycle of the insect pest without harm to the environment. Some investigations proved that zinc is toxic to some insect species. Sastry et al . (1958) reported that Zinc sulfate higher than $800 \mathrm{ppm}$ is toxic to the larvae of the rice moth , Corcyra cephalonica( Stainton) ; Sell and Bodzinck (1971) reported that the pupation of Heliothes virescens (F.) was inhibited when the larval medium was supplemented with $0.1 \%$ or more of Zinc sulfate and caused sever growth depression. A significant growth depression was observed in Bombyx mori larvae fed on diet containing zinc salts at concentrations higher than $400 \mathrm{ppm}$ (Sridhara and Bahat 1966). Sell and Schmidt (1968) recorded developmental abnormalities and inhibition of pupation of the cabbage looper, Trichoplusia $n i$ when its larvae were fed on diet mixed with $0.5 \%$ chelatex zinc. Even at $0.05 \%$ concentration zinc delayed development and occasionally caused developmental aberrations. Salama and Sharaby (1973) reported that zinc sulfate caused sterility of $S$.littoralis when it was mixed with the larval diet. At $0.1 \mathrm{M}$ they found that zinc sulfate has a deterrent feeding effect to the larvae. Sharaby (1987) evaluated Zinc sulfate as possible sterilants against Spodoptera exigua through pupal treatment. Sharaby et al .(2008) recorded that pupae of the red palm weevil, Rhynchophorus ferrugineus immersed in $0.5 \%$ Zinc sulfate solution for 2 minutes caused sterilizing effects to some of the resulted adults. This research aimed at evaluating the effect of zinc sulfate toxicity, on growth and development of S.littoralis .The ultra structure changes of the endocrine glands of the larvae as affected by zinc sulfate larval feeding was discussed.

\section{Materials and methods}

$S$.littoralis eggs were obtained from a standard laboratory culture maintained on fresh Castor bean leaves, Ricinus communis as larval food, under controlled laboratory condition of $27 \pm 2{ }^{\circ} \mathrm{C}$ and $65 \pm 5 \% \mathrm{RH}$ according to Sharaby(1987). 
2.1- Toxicity test: Zinc sulfate was obtained from El Gomhouria CO. Five different concentration as $10,5,3,2,0.5 \mathrm{mg}$ of zinc sulfate $/ \mathrm{ml}$. distilled water were prepared. Castor bean leaves was immersed in each concentration for 10 minutes, left to dry at room temperature then offered to the newly moulted $4^{\text {th }}$ instars larvae. Larvae were allowed to feed on the treated leaves for $72 \mathrm{hrs}$ then provided daily with untreated leaves till pupation. Four replicates of (50 larvae each ) were used for each concentration. Control (untreated) larvae were fed on Castor bean leaves dipped in distilled water only. The mortality percentages of treated larvae were calculated and corrected according to Abbott's formula (Abbott, 1925). Results were subjected to probit analysis (Finny,1971) to obtain the $\mathrm{LC}_{50}$ value.

2.2- Biological test: Newly moulted $4^{\text {th }}$ instar larvae left to fed for $72 \mathrm{hrs}$ on Castor leaves treated with $\mathrm{LC}_{50}$ concentration value of zinc sulfate at the $\mathrm{LC}_{50}$ level, then transferred to untreated leaves till pupation. The larval and pupal duration, pupal weight, percentage of pupation and moths emergence. Biological data obtained were statistically analyzed by (t)test for obtaining significance between the control and zinc sulfate fed larvae data. Numbers of deposited eggs by mated females and percentage of egg hatchability were estimated in each case. Mating process occurred according to the following combinations:

$\mathrm{T}$ females $\mathrm{XT}$ males, $\mathrm{T}$ females $\mathrm{X} \mathrm{N}$ males, $\mathrm{N}$ females $\mathrm{XT}$ males and $\mathrm{N}$ females $\mathrm{X} \mathrm{N}$ males Where $(\mathrm{T})$ treated , $(\mathrm{N})$ untreated or normal moths.

- Ultrastrucutre examinations : Newly moulted $4^{\text {th }}$ instars larvae were fed for $72 \mathrm{hrs}$. on Castor leaves treated with the $\mathrm{LC}_{50}$ concentration of zinc sulfate then left for another 3 days on untreated leaves. The remained living larvae were taken for ultra structure investigations using transmission electron microscope (TEM) fixed immediately in $4 \%$ glutaraldehyde. Untreated larvae of the same age were used as check. Head with thorax were cut from the treated and normal larvae. Specimens were kept in the fixative at $4{ }^{\circ} \mathrm{C}$ till processed. To investigate the ultra structure changes the brain neurosecretory cells, corpus cardiacum,corpus allatum and the prothoracic gland, were examined using the method described by Salama and Sharaby (1985) after investigated by Zies EM/10 electron microscopy at $60 \mathrm{KV}$.

\section{Results and discussion}

3.1 - Table (1) shows the susceptibility of the $4^{\text {th }}$ instars $S$.littoralis larvae towards Zinc sulfate concentration

There was direct correlation between the salt concentration and the percentage of larval mortality. Probit analysis Table(1) recorded the $\mathrm{LC}_{50}$ value as $2.805 \mathrm{mg} / \mathrm{ml}$. Sell \& Bodzinck (1971) reported that $0.2 \%$ concentration of Zinc sulfate had deterrent feeding effects on Heliothis virescens newly hatched larvae, also Salama \& Sharaby (1973) explained that the mortality of $S$.littoralis newly larvae could be related to starvation when fed on diet supplemented with $\mathrm{ZnSO}_{4}$ at $0.1 \mathrm{M}$ or higher, as this lowered the rate of food intake. Insect nutrition regulates the development by activating and control neurosecretory cells in the brain and hormone secretion (Riddiford 1980).

Results in Table (2) showed that $4^{\text {th }}$ instar larvae that was fed on Castor leaves treated with Zinc sulfate at the $\mathrm{LC}_{50}$ level had significantly longer larval and pupal durations. The delaying in development may be attributed to the amount of energy spent by the larvae in order to detoxify zinc sulfate. On the other hand, the mean pupal weight as $389 \mathrm{mg}$ was significantly lowered compared with $485 \mathrm{mg}$ for the control. Percentage of pupation were 67 and 95 for fed and control larvae, respectively. The effect on fecundity and fertility of $S$ .littoralis females

that resulted from the treated larvae that fed on $\mathrm{LC}_{50}$ concentration of zinc sulfate is given in Table (3). The data showed that the lowest mean number of eggs laid per female was obtained form treated females mated with treated males (210 eggs /female), followed by treated females mated with normal males( 270 eggs/female), finally normal females mated with treated male( 368eggs /female), as compared with control (1270 eggs / female). This may indicate that females were more sensitive to zinc sulfate feeding than males . This may be due to accumulation of zinc in females fat bodies. Salama and Sharaby (1973) recorded that the accumulation of Zinc in the tissues of the larvae seems to be the factor leading to the induction of sterility in the emerged moths., Sohal \& Labs(1979) recorded that Zinc sulfate storage as exertion material in the fat bodies of adult housefly Musca dosmestic. Sell and Schmidt (1968) mentioned interference of a metallic ion with basic enzyme system such as cytochrome oxidase and catalase, , would certainly impair growth and development, and interference with the hormone ecdyson could cause moulting difficulties in Tricoplusia ni. The data also showed that in all mating combinations the egg hatch percent was decreased compared with control. Fertility followed the same pattern as fecundity. The lowest egg hatch was obtained on mating combination containing fed ones. Zinc may interfere with oogenesis and spermatogenesis. Ibrahim and Shebl (2002) suggested that reduced female fecundity could be a result of a low metabolic rate. The reproductive activity of the male insects is little affected by nutrition; but all kinds of nutritional factors may influence the production of eggs in females 
(Wigglesworth ,1972). From the foregoing results it could be concluded that Zinc sulfate has considerable toxic effect at highs concentrations and may be considered as disruptor to the endocrine system of the larvae and affect as growth regulator.

3.2- Ultrastrucutre changes of the endocrine glands: Endocrine glands are secretory structures adapted exclusively for producing hormones and releasing them into the circulatory system (Wigglesworth,1972). Hormone is a chemical signal sent from cells in one part of an organism to cells in another part (or parts) of the same individual. They are often regarded as chemical messengers. They may cause profound changes in their target cells. Their effect may be stimulatory or inhibitory. Insects have several organs that produce hormones, controlling reproduction and metamorphosis. Present research described neurosecretory cells of $S$.littoralis larvae located in the dorsum of the brain. They send their axons to the corpus cardiacum from which the secretory material is discharged into the haemolymph. This hormone activates prothoracic gland to secret the hormone that stimulates growth and moulting. Immediately behind the corpus cardiacum is a small endocrine gland, the corpus allatum, which is supplied with nerves from the brain. The corpus allatum secrets the Juvenile hormone and so long as it is present in the blood the growing insect retain its larval characters. In the last larval stage the corpus allatum ceases to secrete this hormone and the insect undergoes metamorphosis to the adult. It then commonly begins once more to secrete the same hormone, which is now needed for the production of eggs in the ovaries. There are several neurosecretory centers in the brain. The largest being parce intercerebralis, consists of a group of connected secretory cells in variable size with big nucleus occupying most of the cell area as shown in Fig (1) of the normal neurosecretory cell of $S$.littoralis larvae. Nucleus is mostly spherical or oval in shape, however in active cells it being irregular in shape thus meeting the greater function demand by an increase in volume, dense cytoplasm containing mitochondria, many secretory granules noticed. Fig (1A) for the neurosecretory cells of the same age of fed larvae cleared small amounts of the secretory granules were observed, clumping in nuclear chromatins, cell cytoplasm appear as fragmented area, appearance of lysosomes as a sign of autolysis of the cell with disintegration of the mitochondria. Golgi apparatus in unactive state as its saccules appear empty of secretion. RER cisterna loss its continuity and appear as swollen vacuole or autophagic vacuoles. Corpora cardiaca are a pair of neuroglandular bodies that are found behind the larval brain and on either sides of the aorta. These not only produce their own neurohormones but they store and release other neurohormones including prothoraciccotropic hormone ( PTTH), which stimulates the secretory activity of the prothoracic glands, playing an integral role in moulting (Gullan and Cranston,2005; Nation,2002). Fig (2) describes section from a portion of corpora cardiaca of normal $S$.littoralis larva. Many dendrites contains neurosecretory granules in variable size were observed. Golgi body between the nerve terminale, number of small mitochondria are present. On the other hand in (Fig .2A) there were enlargement of mitochondria. The cristae of mitochondria increased of the inner chamber of mitochondria, so numerous mitochondria are found in active cell, great quantities of secretory granules, several dendrites in the area of synaptic terminals is expanded it contains mitochondria neurotubules and small synaptic vesicles. These vesicles contain the chemical transmitter hormones, gap junctions in the synaptic area decreased the transmission of chemicals or impulses in the corpus cardiacum cells of of $S$. littoralis fed larvae. Corpora allata are small, paired glandular bodies located on either side of the larval foregut . They secret the Juvenile hormone (J.V) , which regulate reproduction and metamorphosis (Gullan\&Cranston,2005; Triplehorn\&Johnson,2005). Corpora allata of the normal $S$.littoralis larvae in (Fig.3) clearly presented a big nucleus in rough endoplasmic reticulum with small size mitochondria, no secretory granules were observed, while in Fig(3A) an obvious secretory granules or exocytosis of neurosecritiry material within the intracellular cpaces were noticed, synaptic vesicles, clumping in nuclear chromatin, darkening and deformed mitochondria and autophagic vacuoles were observed in the corpora allatum of the fed larvae. Prothoracic glands in $S$.littoralis larvae are diffuse with paired glands located at the back of the head. These glands secrete an ecdysteroid called ecdysone, or the moulting hormone, which initiates the epidermal moulting process (Gullan\&Cranston,2005;Bendeczky and Sehnal,1980). Additionally it plays a role in accessory reproductive glands in the female, differentiation of ovarioles and in the process of egg production. Section through Prothoracic glands in normal S. littoralis larvae (Fig.4), shows group of cells with big rounded nucleus and small mitochondria in the cell cytoplasm. Fig.(4A)for the prothracic gland of the fed larvae, irregular of nuclear membrane, lost of cell membranes, clumping of nuclear chromatin, lysosome noticed in the cytoplasm, fat droplets was observed inside the nucleus, many areas of the cell cytoplasm were encircled by a membrane, leads to the formation of autophagocytic vacuoles, in which cells destroy their own product. Fig. (4B) it is also refereed to as cytoplasmic degeneration leading to sever damage and even death of the cell. The histological changes that noticed between the normal and treated neuroendocrine glands of $S$. littoralis larvae were noticed as increasing in nuclear size, extensiveness of dendrites and mitochondria as a result of overexertion of the cell and increasing of the secretory activity. Fore mentioned changes indicated disorder of the 
treated neurosecretory glands for balancing hormone secretion which effects metamorphosis, development and reproduction of the resulting moths. Sieber(1982) mentioned that Neem extracts increase the secretion in the neurosecretory cells in pars intercerebralis of $E$. varivestis that transferred through corpora cardiaca which activate for releasing B-ecdyson in great quantities leading to disadvantages in cuticle formation and fat bodies. Mittal et al. (1995) recorded that Azadirachtin affected the neuroendocrine system of mosquito larvae. Smagghe et al. (1996) found that Tebufenozide affected the neurosecretory cells of Plodia interpunctella and activated the epidermal cells leading to deformation in cuticle formation and disintegrations in cell organelles as a results of hormonal unbalance. Schluter (1985) recorded that corpora allata and corpora cardiaca cell glands increased in size and degenerated as a result of neem extract treatment for E .vaeivestis. Endocrine system was affected by growth regulators such Tebufenozide which cause damage for the cell organelles as a results of imbalance in hormone secretions (Retnakaran et al.,1997).

It is concluded that zinc sulfate interferes with physiological role of the endocrine glands which modified in their structure and activity leading to disturbed synthesis and release of neurosecretory material, or may affects the endocrine glands activity in an indirect way. Zinc sulfate may be used as a control agent against S. littoralis among other control methods. Salama et al. (1985) showed the remarkable effect of zinc sulfate at $0.1 \%$ in enhancing the potency of the endotoxin of Bacillus thurengiensis Var Kurstaki HD-1 with 16 fold increase. They mentioned the mode of action of the salt may be correlated to its effect on the proteolytic enzymes present in the insect mid-gut. Weiss et al. (1982) mentioned that $0.24 \mathrm{mg}$. of $\mathrm{ZnSO}_{4}$ caused significantly increasing replication of Autographa californica nuclear polyhedrosis virus. Funk and Consigli (1992) indicated that Zinc may have critical role in maintaining virus stability.

Table 1: Susceptibility of $4^{\text {th }}$ instars larval of S.littoralis fed on Castor bean leaves treated with different concentrations ( $\mathrm{mg} / \mathrm{ml}$ ) of Zinc sulfate $\mathrm{ZNSO}_{4}$

\begin{tabular}{|cccccc|}
\hline Tested material & Conc. $\mathrm{Mg} / \mathrm{ml}$. & $\mathrm{LC}_{50}$ & \multicolumn{2}{c|}{ Fiducial limits } & Slope \\
& & & Upper & Lower & \\
Zinc sulfate & 25 & 0.792 & 1.083 & 0.502 & $1.23 \pm 0.145$ \\
& 50 & 2.805 & 3.501 & 2.243 & \\
& 90 & 30.992 & 65.992 & 19.033 & \\
\hline & & & &
\end{tabular}

Table2: Biological aspects of $S$.littoralis fed as $4^{\text {th }}$ instars larvae with $\mathrm{LC}_{50}$ concentration of zinc sulfate (means \pm S.E).

\begin{tabular}{|lcccc|}
\hline Treatment & $\begin{array}{c}\text { Larval duration } \\
\text { (days) }\end{array}$ & $\begin{array}{c}\text { Pupal duration } \\
\text { (days) }\end{array}$ & $\begin{array}{c}\text { Pupal weight } \\
\text { (mg) }\end{array}$ & \% Pupation \\
\hline Zink sulfate & $15.7 \pm 0.21^{* *}$ & $12.40 \pm 0.05^{* *}$ & $389.00 \pm 8.00^{*}$ & 67 \\
Control(Check) & $12.2 \pm 0.30$ & $8.6 \pm 0.10$ & $485.00 \pm 0.24$ & 95 \\
\hline
\end{tabular}

**:Highly significance * Significant at $\mathrm{P}<0.05$

Table3: Number of deposited eggs and egg hatchability for mated females of $S$.littoralis fed as $4^{\text {th }}$ instars larvae with $\mathrm{LC}_{50}$ concentration of Zink sulfate (means \pm S.E).

\begin{tabular}{|c|c|c|c|c|c|c|c|}
\hline \multicolumn{2}{|l|}{$\overline{\mathrm{T}}+\times \mathrm{T}_{\delta}^{\lambda}$} & \multicolumn{2}{|l|}{$\mathrm{N}+\times \mathrm{T}^{\wedge}$} & \multicolumn{2}{|l|}{$\mathrm{T}+\mathrm{N} \times \hat{\sigma}$} & \multicolumn{2}{|l|}{$\mathrm{N}+\mathrm{N} \times \hat{\sigma}$} \\
\hline $\begin{array}{l}\text { Mean } \\
\text { No. eggs/ㅇ } \\
\pm \text { S.E }\end{array}$ & $\begin{array}{l}\text { \% } \\
\text { Egg } \\
\text { hatchability }\end{array}$ & $\begin{array}{l}\text { Mean } \\
\text { No. eggs/o } \\
\pm \text { S.E }\end{array}$ & $\begin{array}{l}\text { \% } \\
\text { Egg } \\
\text { hatchability }\end{array}$ & $\begin{array}{l}\text { Mean } \\
\text { No eggs/q } \\
\pm \text { S.E }\end{array}$ & $\begin{array}{l}\% \\
\text { Egg } \\
\text { hatchability }\end{array}$ & $\begin{array}{l}\text { Mean } \\
\text { No eggs/o } \\
\pm \text { S.E }\end{array}$ & $\begin{array}{l}\% \\
\text { Egg } \\
\text { hatchability }\end{array}$ \\
\hline $\begin{array}{l}210 \pm 1.2 \\
(83.47)\end{array}$ & $\begin{array}{l}31 \\
(86.37)\end{array}$ & $\begin{array}{l}368 \pm 2.5 \\
(71.02)\end{array}$ & $\begin{array}{l}38 \\
(61.22)\end{array}$ & $\begin{array}{l}270 \pm 2.4 \\
(78.74)\end{array}$ & $\begin{array}{l}34 \\
(65.31)\end{array}$ & $1270 \pm 6.5$ & 98 \\
\hline
\end{tabular}

Values between brackets represent percentages of reduction as compared with control.
$\mathrm{T}$ :Treated
$\mathrm{N}$ : Normal untreated 


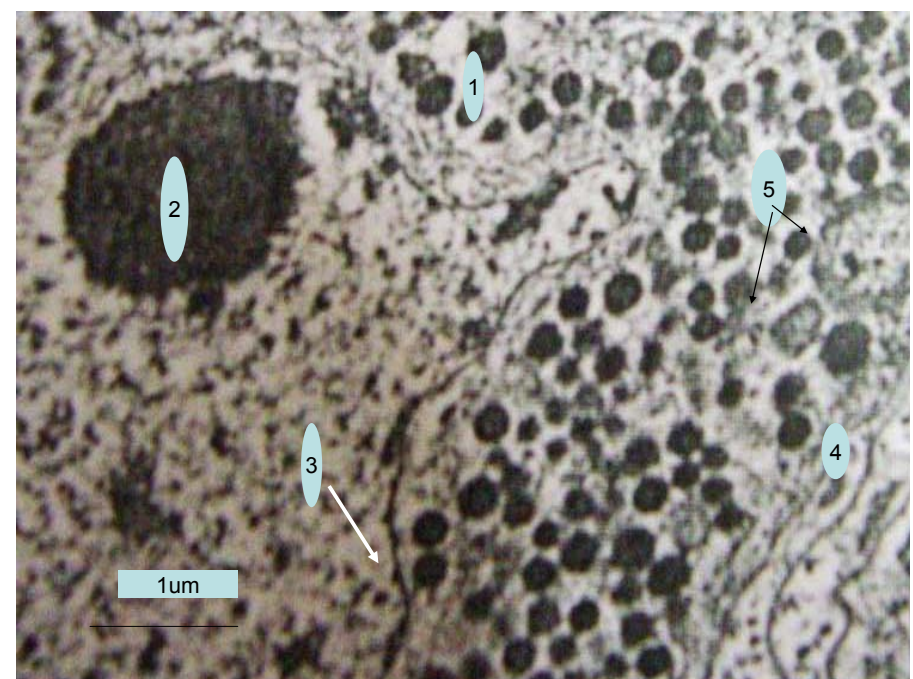

Fig1: Section through normal neurosecretory cells in the brain of S. littoralis larvae showing many secretory granules (1) ,big nucleolus(2), nuclear membrane (3) ,cell membrane (4) ,mitochondria (5).

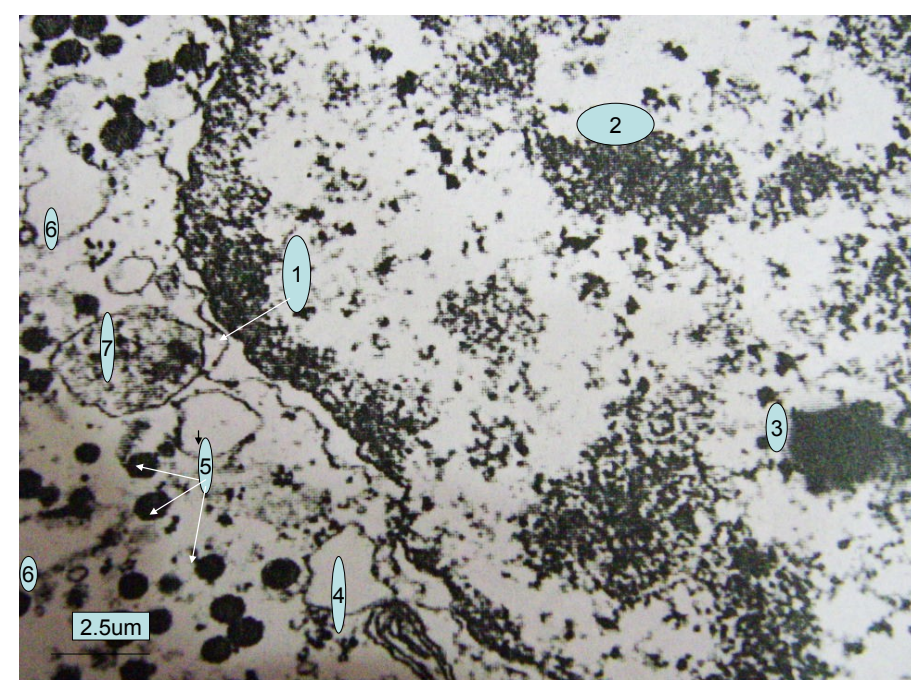

Fig1A:Section through: the neurosecritory cells in the brain of the fed larvae of S. littoralis nuclear membrane(1),nuclear chromatin(2),nucleolus(3), Golgi body(4), secretory granules(5), vacuoles(6), autophagic vacuoles(7).

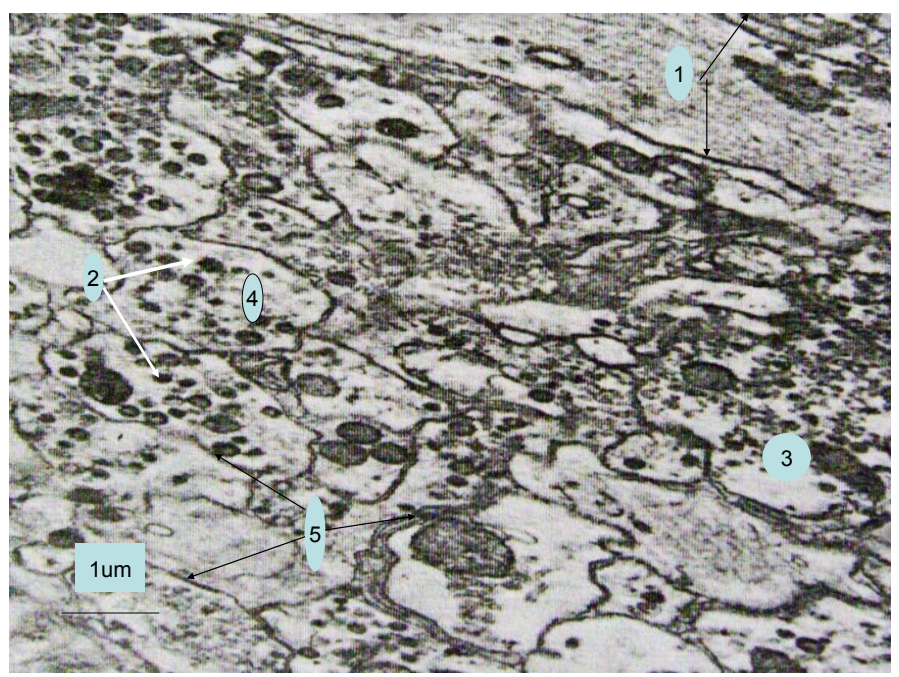

Fig2:Section through normal corpus cardiacum of S.littoralis larvae showing membrane of axon of the secretory cell(1),secretory droplets in variable size(2),mitochondria(3),dendrites(4)denderitic membrane(5). 


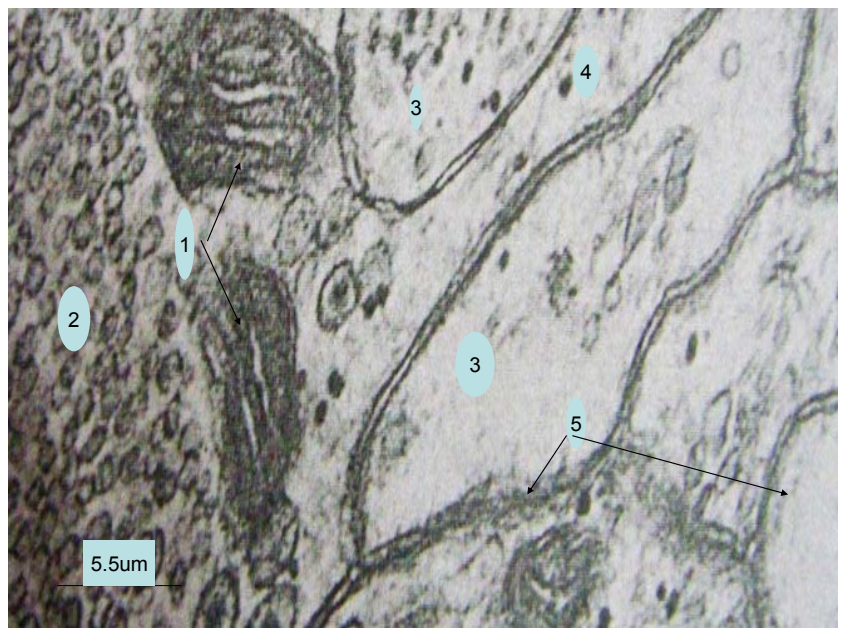

Fig2A:Section through Corpus cardiacum of fed larvae of $S$. littoralis clearing the enlargement of mitochondria(1),great quantities of small secretory granules(2),extensiveness of the dendrites(3 )dark granules(4), dendritic membrane(5)

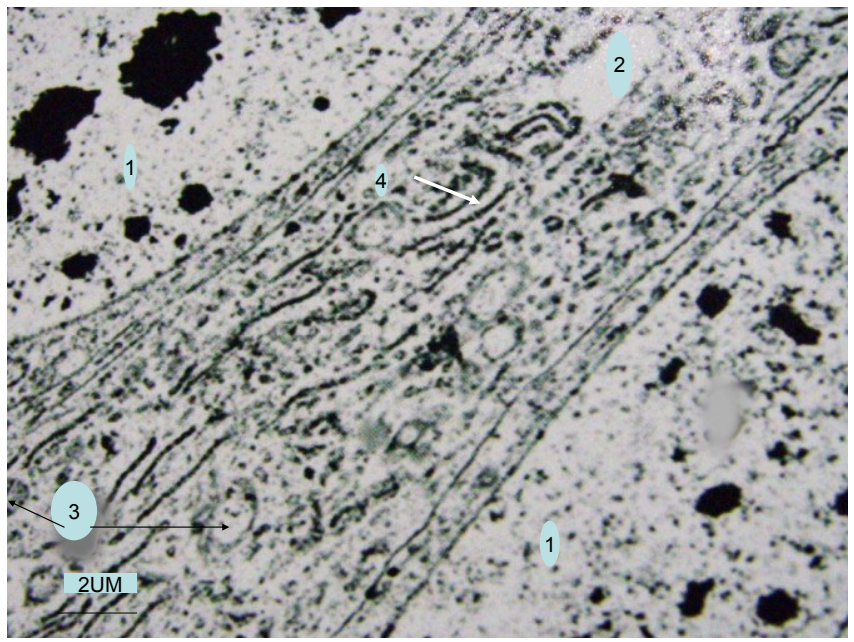

Fig3:Section through Corpus allatum of normal larvae of $S$. littoralis .Nucleus(1), Rough endoplasmic reticulum(RER(2),mitochondria(3), Glgi body(4),

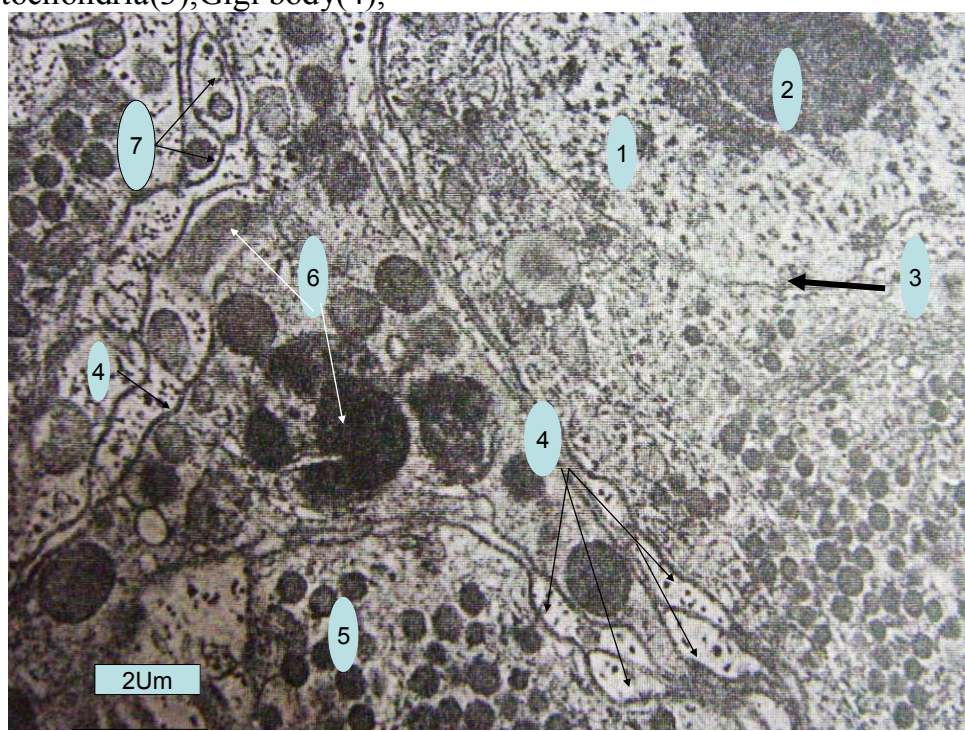

Fig3A:Section through Corpus allatum of fed larvae of S.littoralis showing nuclear chromatin(1),nucleolus(2), irregular nuclear membrane(3), dendrites(4), secretory droplets(5),twisted mitochondria(6). Autophagic $\operatorname{vaceoles}(7)$ 


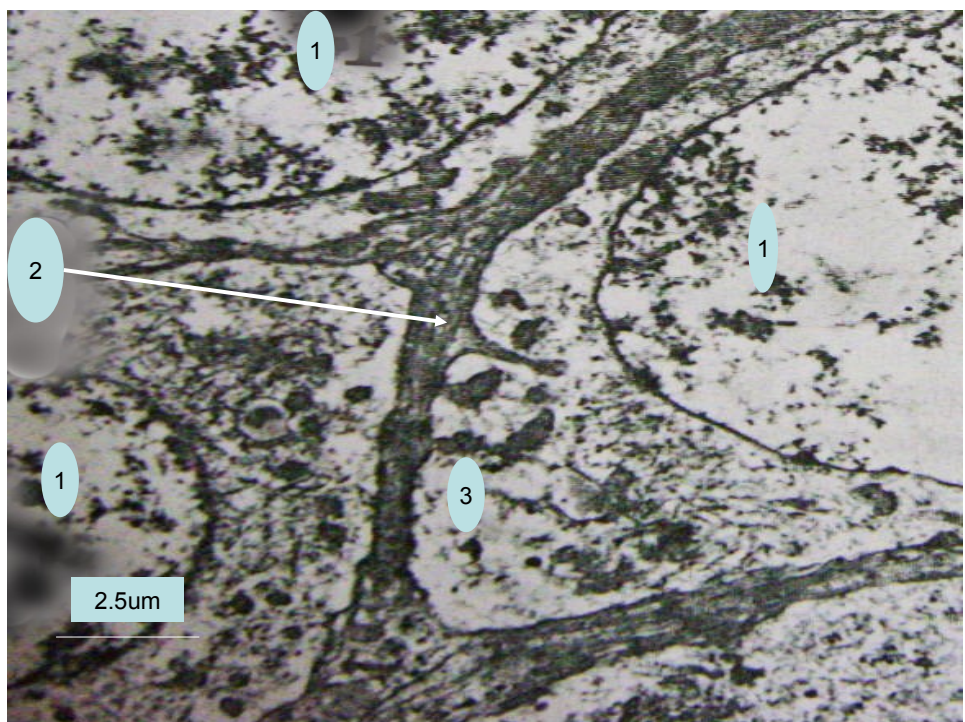

Fig4:Section through Prothracic gland of normal $S$.littoralis larvae.Nucleus(1),cell membrane(2),mitochondria(3).

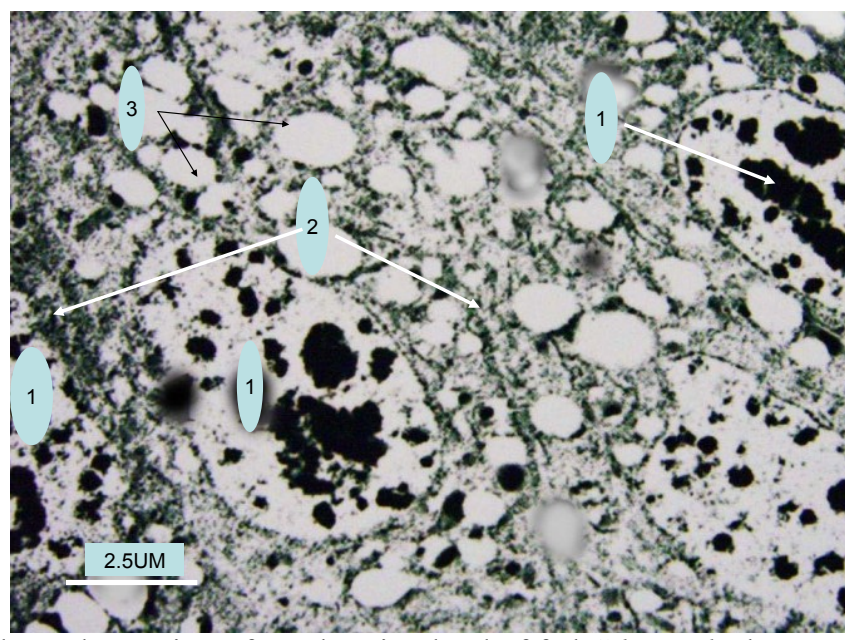

Fig4A:Section through portion of Prothracic gland of fed S.littoralis larvae,showoingnuclear chromatin(1).,degeneration of cell membrane(2),vacuoles(3).

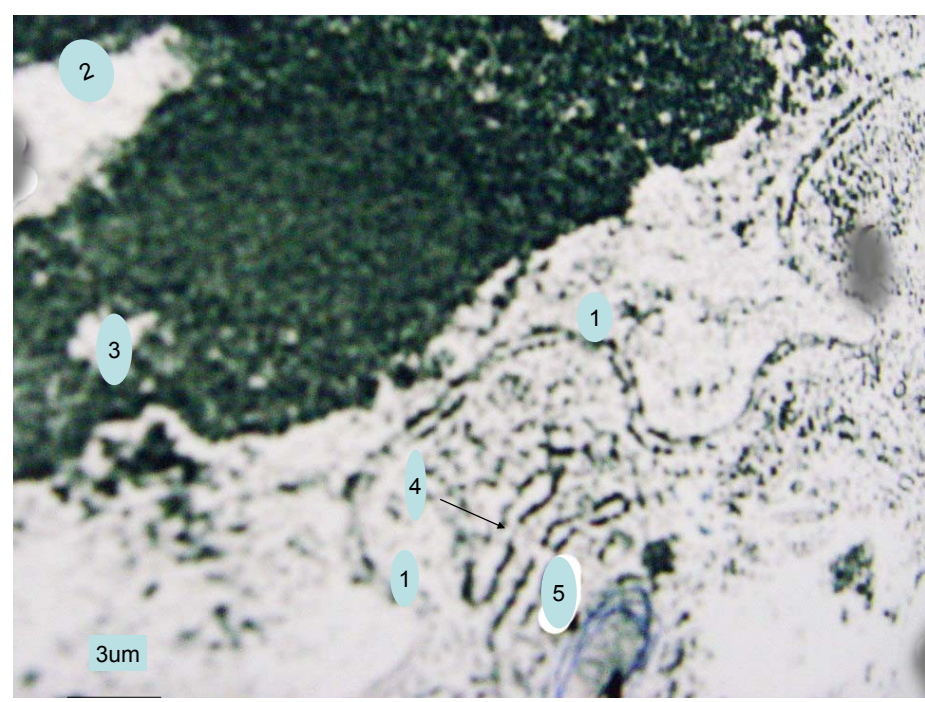

Fig4B:Section through Prothracic gland of fed larvae of S.littoralis, clearing irregular nuclear membrane(1), fat droplet(2), clumping of nuclear chromatin(3), golgi body(4), lysosome(5). 


\section{References}

[1]. Abbott,W.S.1925.Amethod for computing the effectiveness of an insecticides. J. Econ. Entmol., 18:265-267.

[2]. Bendeczky,J.M and F.Sehnal.1980. Ultrastructure study on the innervations of prothoracic gland in Galleria mellonella. Endocrynology.4(3):400-407.

[3]. Finney,D.J.1971. Probit analysis . ( $3^{\text {rd }}$ ed; Cambridg. Univ. Press, U. K).

[4]. Funk,C.J and R.A.Consigli.1992. Evidence for Zinc binding by two structural proteins of Plodia interpunctella granulosis virus.J. Virology,66(5):168-71.

[5]. Gullan,P.J; P.S.Cranston.2005. The insects: An outline of entomology( $\left.3^{\text {ed }}\right)$.Oxford: Black Weel Puplishing.61-650.

[6]. Ibrahim,A.K.A and D.E.A.Sheble.2002. Biological parameters for evaluating the effect of insect growth regulators against grasshopper, Euprepocnemis plorans plorans (Chap.) and cotton leaf worm, Spodoptera littoralis (Boisd.) J Agricul.Res. 80(2):5715810

[7]. Mittal,P.K; T. Adak;and V.P. Sharma.1995.Bioeffecacy of six neem (Azadirachta indica ) products against mosquito larvae.Pesticide.Res.J.7(1):35-37.

[8]. Nation,J.L.2002. Insect physiology and biochemistry.CRC Press. 113-455.

[9]. Rentakarn, A; A. Macdonald; W. Tomkins; C. David; A. Brownwright and S.R. Palli.1997. Ultrastructure effects of non-steroidal ecdyson agonist, RH-5992, on the $6^{\text {th }}$ instars larvae of the spruce budworm, Cheristoneure fumiferana (Bibliographic citation) J. Insect Physiology, 43(1): 55-68.

[10]. Riddiford,L.M.1980. Insect endocrinology :Action of hormones at the cellular level. Ann . Rev. Physiol,42: $511-528$.

[11]. Salama, H.S and A. Sharaby. 1985. Histopathological changes in Heliothis armigera infected with Bacillus thuriniensis as detected by electron microscopy. Insect Science\& Applic. 6 (4): 503-511.

[12]. Salama,H.S;M.S.Foda;and A, Sharaby.1985. Potentiation of some chemicals to increase the effectiveness of Bacillus thuringiensis against Spodoptera littoralis .Z.Ang.Entmol.100:425-433.

[13]. Salama, H.S. and A. Sharaby. 1973. Effect of Zinc sulphate on the feeding and growth of Spodoptera littoralis ( Boisd.).Z.ang.Entmol.72.(1972/73):383-389.

[14]. Sastry,K.S; R.R.Muth and P.S.Sarma .1958. Studies on the Zinc toxicity in the larvae of the rice moth Coryca cephalonica Biochem.J. 69, 425-428.

[15]. Schluter, U. 1985.Disturbance of epidermal and fat body tissue after feeding azadirachtin and its consequence on larval moulting in the Mexican bean beetle, Epilachna varivestis (Col. Coccinellidae) Ent. Ger. 10:97-110.

[16]. Sell, D.K. and C.V.Schmidt.1968.Chelating agents suppress pupation of the cabbage looper. J. Econ. Entomol. 61: 946-9490

[17]. Sell, D.K. and D.A. Bodznick.1971. Effect of dietary $\mathrm{ZnSO}_{4}$ on the growth and feeding of tobacco bud worm, Heliothis virscens . Ann.America. Entomol. Soc. 64: 850-855.

[18]. Sharaby,A.1987. Screening of certain inorganic salts as possible sterilants against the lesser cotton leaf worm , Spodoptera exigua(HBN.), by pupal treatments.Bull.Ent.Soc.Egypt.16:269-282

[19]. Sharaby,A ;F.El-awari and S.A.Ibrahim. 2008. Some inorganic salts for production of sterile adults of the red palm weevil Rhynchophorus ferruginous (Coleoptera:Curculionidae). Egypt. Acad.J. biolo. Sci;1(2):205-210.

[20]. Sieber, K.P. 1982. Untersuchngen uber die wirkung des Azadirachtin auf die Entwicklung und ihre steuerung bie Locosta migratoria Ph.D. Thesis, Univ. of Munich, FRG.

[21]. Smagghe, G; H. Salem and D. Degheede.1996. Tebufenuzide effects on nonsteroidal ecdysreroid agonist on cuticle formation in Indian meal moth, Plodia interpunctella larvae. (Bibliographic citation).Parasitica.52(4):143-151.

[22]. Sohal,R.S and R.E. Labs. 1979. Storage excretion of metallic cation in the adult housefly, Musca domestica. J. Insect. Physiol., 25 (2):119-124.

[23]. Sridhara, S. and J.V. Bahat. 1966. Trace element nutrition of silkworm, Bombyx mori L. I. Effect of trace elements. Proc. IndianAcad. Science: 9-14.

[24]. Triplenhorn, C.A. and N.F. Johnson. 2005. Borror and Delong's Introduction to the study of insects ( $7^{\text {th }}$ ed). Brook/Thomson Cole USA.

[25]. Wiess,S.A;G.C.Smith,J.L.Vaughn,E.M.Doughert G.J.Tompting.1982.

[26]. Effect of aluminum chloride and Zinc sulfate on Autographa californica nuclear polyhydrosis virus (ACNPV) Replication in cell culture.Tissue culture Association . 18(1):937-9440

[27]. Wigglesworth,V.B.1972. The principles of insect physiology.English language Book Society. Chapmann \&Hall,England. $170 \mathrm{p}$

[28]. Wiegglesworth, W.B. 1965. The principles of insect physiology. E.P. Dutton \& Co., New York, 453p. 